\section{INTERNET BOOTHS IN VILLAGES OF INDIA}

\section{Sundari Krishnamurthy ${ }^{1}$}

\begin{abstract}
Over 700 million of the 1050 million of the population in India live in the villages in which agriculture is the main occupation, thus making every fourth farmer in the world an Indian farmer. The average Indian farmer has to manage multiple relationships on a day-to-day basis: he has to weigh the choices in the inputs- seeds, fertilizers, pesticides etc; he has to network with various agencies and services ; for managing his farm he needs accurate, timely and adequate information. Can modern information technology aid the Indian farmer is the focus of this paper and examines the I.T efforts made by the academia, universities, intelligentsia, scientists, research institutes, government and privates sector organizations. Case studies of women from 106 interviewed families in South India showcase the achievements of rural women in Self Help Groups who are linking globally and acting locally. This gives a peep hole into the possibility, of India reaching the highest growth rate, in the Internet market in the Asia Pacific region in the next five years!
\end{abstract}

Mahatma Gandhi used to often remark that "India lives in its villages". Over 700 million of the 1050 million population live in the rural areas in which agriculture is the main occupation. Agriculture continues to be the critical base in India, for it provides food to the huge population and also

\footnotetext{
1 Department of Sociology, Stella Maris College, Chennai, India
}

provides self-sufficiency in food grains to the nation. Over the years, through the Green Revolution, India has been able to export food grains to other countries and thus earn foreign exchange, which is valuable in repaying international loans.

In a predominantly agricultural country like India, an evergreen farm revolution based on higher productivity in perpetuity is the best safety net against hunger and poverty. Soon after independence in 1947, the First Prime Minister of India, Jawaharlal Nehru, remarked, "everything else can wait but not agriculture". This pronouncement was reflected in several public policy and investment decisions, particularly in the areas of irrigation, fertilizer production, land reforms and community development. ${ }^{2}$

India's economy is said to be the eleventh largest in the world and its gross national income was close to 500 billion US dollars in 2002. But at 460-470 dollars per capita, India ranks (162) way below most nations, if we take into consideration the population size and the relatively lower rate of economic growth until the start of the 1980's. ${ }^{3}$ Added to this is the fact that income is not uniformly distributed in India. There is very wide disparity between the very rich and the very poor. Eighty-five percent of the country's wealth is concentrated in a fifth of the country's people. A burgeoning middle class accounts for another $11.5 \%$ of the country's wealth, while $40 \%$ of the country's people are at the bottom of the pyramid and have access to only $3.5 \%$ of the total wealth in the country.

\footnotetext{
${ }^{2}$ Prof.M.S. Swaminathan (2004), Manorama Yearbook 2004, p 523.

${ }^{3}$ S. Sethuraman (2004), Manorama Yearbook 2004, p 512
} 
Poverty reduction is possible only through gainful employment. Two hundred and fifty million new jobs are needed by 2015 . Agriculture can absorb no more than 25\%. Therefore, India must create 15 million new, non-agriculturally related jobs. China is making huge strides in promoting an integrated rural on- farm and off- farm employment scheme. The self- help groups supported by micro-credit, is a revolution, which if carefully nurtured by market driven enterprises, can provide the income to maintain food security at the household level for the asset-less population, i.e., those who have no land, livestock or productive skill. Many farmers in the rural areas belong to this category, and these people have to be uplifted, if India is to achieve its target of development, which is optimistically set at 2020, by the current President of India, Dr. A.P.J.Abdul Kalam.

The road to agricultural development is neither straight nor smooth. Lower farm incomes have been caused by falling agricultural prices. Globalization has brought in its wake low - cost food imports. The average Indian used to dry wheat grains in the sun and then grind them in the local flour mill. This homely product now has competition from imported packaged wheat, like- Pilsbury. Moreover, lifestyles and habits are changing even in the rural areas. Farmer's sons are now open to Western and urban influences. Climatic changes make life even more difficult for the Indian farmer, who has always been "monsoon-dependent". The economic and political climate is also not very good as interest on credit is high. There are a large number of middlemen in the agrarian economy. The Government's support by way of subsidies and other benefits have either been reduced or have disappeared over the years.
The average Indian farmer has to manage multiple relationships on a day-to-day basis. He has to weigh the choices of investments: seeds, fertilizers, pesticides and equipment. $\mathrm{He}$ has to network with various organizations, agencies and services from the Government, private and co-operative sectors for managing his land and crops. For all of the management functions of planning, organizing and implementing, the farmer requires adequate, timely and accurate information-which has a very high cost. In this Catch 22 situation, we have to ask the million dollar question: Who can help the Indian farmer? Is it academia, intelligentsia, scientists, research institute, the government or private sector?

The information technology industry is viewed by India as the major hope for expanding its economy and generating development in rural areas. This is clearly visible in the current telecommunications scenario. While earlier the telephone was viewed as a luxury, it is now clearly perceived that telephone communications is vital for socio-economic development (McDowell, 1997). Transactions are speedier through the telephone, business and service operations are more efficient and the economy is able to bring more benefits to many people.

Rajiv Gandhi, the former Prime Minister of India, launched a technology mission through Sam Pitroda and put India on the path of informatization strategy of development in the 1980's (Pitroda, 1998). Development scholars define "Informatization" as the process by which communication technologies are used as strategies for furthering socio-economic development (Singhal \& Rogers 2001, p.19). Politicians like Manmohan Singh, bureaucrats like N.Vittal and technocrats like T.Hanuman Chowdary speeded up this 
revolution in the 1990's ( Vittal ,1999). Rural and urban India is now connected with the establishment of digital automatic exchanges and 650,000 public call offices (PCO's). Tele-communication, which originally meant mainly telephone services, in recent years has come to connote satellite transmission as well as computer communication.

A historical look will help put these changes in perspective. When India gained independence in 1947, its 350 million population had only 84,000 telephones. By 1980, India had a population of 700 million and only 2.5 million telephones and 12,000 public telephones. However, by 1990, India's telecommunication network became the ninth largest in the world, since it had installed over 25 million telephone lines, spread over 300 cities, 4869 towns and 310,897 villages (Bahadur, 1999). More than the numbers, the quality of life of people living in the remote, hilly, tribal and rural areas improved, as they were now connected to the mainstream of Indian society. Prior to this revolution in communications, there had been a telephony-divide, for $90 \%$ of telephones were in found urban areas, even though about $75 \%$ of the Indian population lives in rural areas.

In the 1990's, the expansion of telephones primarily took into account the needs of the business and service sectors and the upperclass urbanites. While earlier only $4 \%$ of the villages had telephones, by the year 2000 nearly half of Indian villages had access to telephones (Westerveld and Prasad, 1994). The PCO's with their bright yellow signs connected the poor and marginalized villagers to their families and marketplaces and thus gave them a critical competitive edge. Pitroda equipped ordinary telephones with a small meter and this equipment was sold to entrepreneurs, who set up manned public call offices (PCO's) in rural and urban areas (Pitroda, 1993). These telephone entrepreneurs are billed only six times a year and get a $25 \%$ commission on their revenues. The metered telephones are in so much use that the income from one telephone is enough to sustain a family. The PCO is a tool of communication for the community and a source of income and employment for the individual.

In India, an indigenous Wireless Local Loop (WLL) system was developed, with a high quality two-way radio connection between a telephone and a local exchange. A more recent version has been developed by Midas Communication Technologies of Chennai in collaboration with the Indian Institute of Technology's Electrical Engineering Department, Chennai and U.S Analog Devices and has been installed in villages near Chennai. ${ }^{4}$ Offering highspeed data transmission facilities, Internet access and ISDN services, this CorDect version of the WLL, costs only \$ 275 (U.S) for installation, as compared to the cost of $\$ 750$ (U.S) to install a regular wired telephone line. Though India missed the telecommunication boom of the 1980's, which spurred the economies of Taiwan, Hong Kong, Korea and Singapore, this new CorDect technology is poised to bring about great socio-economic changes in the rural areas of India.

Setting up a kiosk costs the village entrepreneur only about $\$ 1,000$, for which each person gets a telephone with Internet, multi-media PC with web camera and printer, and a four-hour power backup for the PC. Initial training is provided on

\footnotetext{
${ }^{4}$ Ashok Jhunjhunwalla (2004), rediff.com
} 
operating the system, and Indian language software is provided. Creativity and enterprise and a \$ 60 monthly income are alone required to break even. ${ }^{5}$ The success stories from these Internet booths, run mainly by women, are already making dramatic stories. A 60 year old woman who had lost vision in both eyes used the telemedicine link-up. Though living in the village of Melur, Palaniamma's eyes were beamed through the web camera to the Aravind Eye Hospital in the city of Madurai. Doctor's gave her a diagnosis that she could regain vision in one eye, which she later did by visiting the hospital and getting the appropriate treatment. A chicken's lame leg was beamed to the vet through the web cam and the necessary diagnosis and treatment were provided through voice mail ${ }^{6}$.

Time, travel and money were saved for the villagers and timely solutions were also obtained. A farmer was able to save $\$ 3,000$ and his crop of okra when the entire field got infected with yellow mosaic disease. The web camera was again used to send a picture to the distant Agricultural University, from where agricultural scientists could give the necessary instruction for spraying and treating the crops- and all for the price of $\$ .40$ which was the charge for having used the Internet! Now the villagers are demanding that their children should be made to pass the crucial school exams of $10+2$. The charismatic Professor Jhunjhunwalla has now formed a team of academicians to write educational software, and graduate student engineers have devised a multi-video communication system (called IIT-OOPS) to facilitate

${ }^{5}$ Ashok Jhunjhunwalla and others (1998), IEEE, p.1

${ }^{6}$ http://in3.org/articles/IIT.htm video-conferencing so that village children can be "coached" through the Internet booths. Communication through the Internet booths is the magic mantra for village development. In the future, the Internet booth in the village could even function as a micro - bank or Virtual University according to this dynamic academic group in Chennai, which has also set up a group of companies to take charge of the various activities which have expanded from the setting up of the rural Internet booths.

Prof. M. S. Swaminathan, a world renowned agricultural scientist, embarked on setting up rural knowledge centers for information empowerment, employment generation and livelihood security in the Union territory of Pondicherry in the late 1990's. Solar panels provided power, and wireless technology has been able to connect vast rural areas with urban marketplaces in Pondicherry, about 500 kms from Chennai (Sundari. K, 2000). Information is downloaded at the main research insitute of MSSRF at Taramani, Chennai and sent by dish or Internet to the local station at Villianur, where the value addition is done by local experts to make the knowledge local specific and demand driven.

The fishermen at Veerapattinam village have immediately derived benefits by way of safety and security. Wave heights are downloaded from a U.S Navy website at Chennai and sent to Villianur, where the local providers obtained the information for the seas near Pondicherry. A super cyclone was brewing in the Bay of Bengal in 1999 and timely warning through two - way radios and notice boards posted outside the Internet booth alerted the fishermen, who 
thus did not venture out into the sea and many lives were saved ${ }^{7}$.

Prof. Swaminathan drew up an MOU which is signed by the village community. They are not mere beneficiaries receiving handouts, but partners in the developmental process. The village community had to provide rent-free, quality space for the Internet booth and electricity. They had to depute volunteers $(50 \%$ had to be women) for the running of the booth and also protect the equipment from vandalism. The technical staff from the research InstituteMSSRF- provided the requisite training, both for running the and for running the hardware and software.

The village booth operators have been innovative, original and creative. One young woman in Pondicherry devised a method of teaching the women in her village how to vote in the new electronic voting machines, introduced for the first time, when women were contesting for Panchayat seats in local government. This young woman was a commerce graduate from a college in the nearest town, as was her brother. Her father was a farmer and they lived together in a joint family - the two older married sons, their wives and children, together with a widowed aunt and the younger unmarried son and daughter. All lived under one roof and shared meals and resources jointly.

At about this time, new legislation was enacted in Parliament at Delhi which opened up the possibility of women standing for election at Panchayat, by which they could participate in local selfgovernment. Along with this came the exciting news that a new device - an electronic voting machine - would be used

${ }^{7}$ Sundari.K (2000), research report page 21 for this election and it would be speedy and accurate. Most people felt that the huge rural population in India, which was usually illiterate and not very technology savvy would find it difficult to use this machine. There would either be a large number of invalid votes, if people came to vote or if large numbers of people would not vote because the new technology would put them off. This was the thought of even the election officials, who toured the villages- publicizing, educating and training the opinion leaders of the villages.

The sister-brother duo listened to the election officials when they came to their village and hit upon the idea of simulating a voting machine on their computer complete with names of candidates and their election symbols. India has a multiparty system and even with a paper vote, the huge list of candidates and their many symbols can confuse anyone. There were buttons in the visual on the computer and were indicated on the screen. When a person 'pointed' with their mouse and clicked or registered their vote, they could see for themselves whether their vote had registered or it had become cancelled through improper voting. Large numbers of people in the village flocked to "learn" how to vote electronically. The women of the village especially were tutored individually, by this enterprising young woman, so that in turn, there was the highest turnout of women voters in the election. ${ }^{8}$

Another enterprising young woman Sundary, downloaded a Government entitlement form and obtained free bicycles for her village children by talking to parents and village school teachers, and even targeting children and convincing them to

\footnotetext{
${ }^{8}$ Sundari.K(2003), Law and Society, P 16
} 
apply for the scheme. She saw a web posting for daily- work for men and promptly printed it. Instead of merely sticking it on the notice board she walked around the village and spoke to the men (often lounging idly) or to the wives (at the village water taps) and thus many houses had food in their pots because of her. Similarly, free entrepreneurship training for women to start self-help groups (SHG's) and self-employment schemes next attracted the eye of Sundary on the web and she set off with missionary zeal through her village. Man, woman and child benefited more from one woman with her vision with the Internet! ${ }^{9}$ The Swaminathan foundation was awarded the Motorola award and Stockholm certificate for extending technology for rural development.

The Government in India has been responsible for providing the "backbone", that is the hardware for the Internet Revolution in India. It has also not lagged behind in providing schemes for social development in the villages. Working with NABARD - the National Bank for Agriculture and Rural Development- in 2001, a scheme was announced for setting up Agri-clinics and Agri-business centers. Annually about 11,900 students graduate from agricultural universities in India. Of these, about 5500 join graduate programs, and about 2000 find employment in the private or government sectors. There is still a large pool of graduates who can be utilized for providing technical and extension services to the farming community.

The Indian Council for Agricultural Research (ICAR) undertook a survey of farmers and agricultural students and obtained feedback from them about the proposed network. The farmers stated that

${ }^{9}$ Sundari.K (2002), ISA at Brisbane, Australia, p.6 they would welcome such a move and would even pay on the basis of the quality of services provided. The farmers mainly wanted water and soil quality testing, livestock health cover and extension consultancy services. The agricultural students were very happy that a rural network of agri-clinics was to be set up. They expressed the need for intensive training in entrepreneurial skills and also wanted training in business management, finance and accountancy, for which they were willing to pay. Backed by the findings of the acceptability survey conducted by ICAR, NABARD launched the scheme to set up rural agri - clinics to work for rural development, in which education and technology would work hand - in - hand.

Many in the corporate sector have also entered the boom in rural Internet booth installations. One of the doyens of Indian industry, J.R.D. Tata had stated that Indian industry must function like a 'trustee' and therefore discharge their functions to society with maturity, responsibility and care. Most industries, especially those working with farmers, have functioned with this concept of trusteeship. Also, because they are important stakeholders in the rural areas, they have undertaken village Internet booth projects.

Gyanada is one such rural venture at Baramati in Maharashtra ${ }^{10}$. Creating a very classically Indian logo of Gyananada or Kamala- a goddess embodying Laxmi, the goddess of wealth, and Saraswati, the goddess of knowledge, they are committed to spread knowledge for prosperity. In a region rich with sugar cane and other agricultural produce, the Internet booths are located in every existing building - be

\footnotetext{
10 Dr. Manu Seth (June 1, 2001) on Gyanada.com
} 
it village godown, post office, railway station and milk collection center, as the philosophy was to use every brick and mortar and not waste resources on putting up new buildings. This is a very refreshing approach as a greater part of the funds allocated for development in the 1960's were often squandered on buildings and infra - structure development. The villages were connected and as the booths started working, band- width and other hardware problems were sorted out as they arose. A two-tier pricing was adopted. No fees or very low fees were collected from the poor, and others were charged a fee much lower than the commercial rates. Many villagers flocked to the booths, as they wanted to obtain information on health or for schemes to add to their incomes or just to keep up with the Joneses!

Three tiers of customers for the Internet booths emerged: firstly, individuals who came to use the telephone or e -mail; secondly, retailers, traders, transporters, labor contractors and others in trade; and thirdly, people who wanted to use the Internet long- range and for whom a special 3-5 year rate was fixed. Maharashtra leads in India in commercial and agricultural enterprises, and the farmers' use of the Internet booths is a factor.

Dristhee in Central India is a huge rural network of Internet booths reaching out to 8 million of the deprived tribal population. ${ }^{11}$ Awarded the prestigious Stockholm Challenge Award 2000 for 'public services and democracy', Drishtee has as its mission that of connecting India, village by village. Starting with a realistic analysis of the villages in India, which has a total population of about 71 crores, who live in about 5,750,000 villages throughout India.

${ }^{11}$ dristhee.com
The average village population is about 1,250 people. The average rural per capita income is Rs. 7500/- (45Rs. = 1 US \$); the average village GDP is Rs. 1.05 crore and the total rural GDP is Rs.593,250 crores. Given this financial background, Drishtee attempted to strengthen the rural economy.

Drishtee adopted a multi-pronged strategy to achieve this objective: creating employment opportunities in the villages, providing a vital link between the rural market and the rural service providers, and developing a strong infrastructural base for the physical delivery of rural products. Technology experts like Sam Pitroda (1993) have shown in the village study at Tumkur, Karnataka that by connecting the village by a telephone exchange and providing telephones in the villages, there can be socio-economic betterment in the village. Pitroda was able to provide empirical evidence of this fact by conducting a before-after socio-economic survey of the village, and one startling fact emerged from this- the savings of the villagers rose by about $300 \%$. Development scholars like Singhal and Rogers (2001) have provided significant information in a study of the Kittur rural telephony project ${ }^{12}$. A telephone exchange was introduced in mid 1986 and 74 local farmers were provided telephones, through which they made 2,400 phone calls per year. An evaluation of the impacts of telephones on the village "found an 80 per cent increase in cash deposits at local banks, an increase of 20 to 30 per cent in local business incomes and more rapid access to doctors for local residents in case of emergencies." 13

\footnotetext{
${ }^{12}$ Singhal,A \& Rogers,E.V (2001), Chapter 5: The Telecommunications Revolution, pp 183206.

${ }^{13}$ Ibid, p 207
} 
The Internet booths in the tribal villages became an effective vehicle for rural promotion. The Government of India, state governments, banks, other social service organizations and non-governmental organizations (NGO's) have several schemes and programs for tribal /village development. But there is many a slip between the cup and the lip. The intermediaries and middlemen often serve as a stumbling block to development. Information Technology was able to provide a direct link between the villagers and institutions and so tribals could get loans from banks or certificates (e.g. birth and death certificates) from local government departments and subsidies and other entitlements from government schemes directly, through using the Internet booths.

By also using IT as a basic tool for education and facilitating health care and other infrastructure facilities, Drishtee is aiming to reverse the tide of rural migration. The Government of India from the millennium is renewing its efforts to "rurbanize", that is urbanize the rural areas, with redoubled vigor. Drishtee, with its attempts to form a chain of computer literate village entrepreneurs, are partners in this new concept of development. The Internet is enabling a flow of knowledge services and products to and from the vast base of users and consumers.

In Uttar Pradesh, Technology and Action for Rural Advancement (TARA) aims to enable the rural economy to leap - frog into the twenty-first century ${ }^{14}$. So far the results show financially sustainable, Internet-based booths with powerful revenue streams. How have they been able to achieve this? Through TARA kiosks, TARA gyan and

${ }^{14}$ TARAhaat.com
TARA haats. TARA Internet kiosks offer a basket of products: information, education, training, services and goods. IT skills, life skills and vocational skills are imparted to the villagers through the Internet booths. Tara Gyan provides education to the villagers on IT in the local languages. With 1,652 languages in India, of which 33 languages are 'mother tongues' each spoken by a population of over a million, and 18 official languages, the Internet booths in each State need to provide instruction and communication through the local languages and dialects. Certification is given to the villagers after adequate teaching, training and testing.

TARAhaat is aiming in the future to have TARA gurus, TARA cards and a TARA university. The TARA gurus would be barefoot village consultants networking the vast rural areas. The TARA cards would facilitate the rural users much like credit cards do the urban users. The TARA University would provide in-house training and pave the way for increasing literacy in the villages. TARAhaat.com is already bridging the digital divide in Northern India, by connecting the rural communities to the global village, and it is creating digital dividends!

EID Parry, of a Tamil Nadu Corporate group, adopted the Cordect technology and set up Internet booths in the villages of Nellikuppam, near Cuddalore, as part of the Group's corporate strategy for social responsibility. Since this corporate group of companies has many businesses which are based on agriculture, it had both the infrastructure and the human resources to start this kind of project. Web pages were designed for different aspects of agricultural activity, like sowing, planting, and reaping, and input of seeds, pesticides, fertilizers and markets were also provided. 
The needs of the community had been assessed by base-line surveys, and web pages on health, education, selfemployment and schemes for women were also provided ${ }^{15}$. The community was made a partner in this developmental communication enterprise. While the organization provided the infrastructure of the Internet booths and the web page, some members of the village community (many women) invested a certain amount of money to take on the ownership of running the Internet booths. I will attempt to capture the attempts made by several women in these rural villages of Tamil Nadu, a State in South India, to cross socio-economic, political, cultural and geographic borders. Women from 106 families were interviewed on an individual level. Gender was considered an important variable in this study, as new technology can come into a social group and yet the very same technology can create a technology barrier to women. Women in various age groups formed the subject of study and Figure 1 captures this profile.

\section{Figure 1: Age Composition of Women}

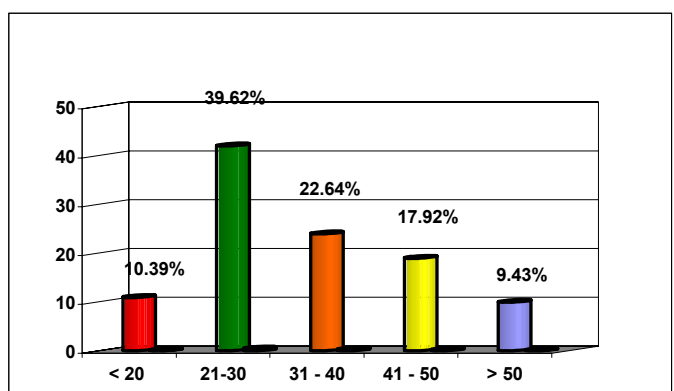

Some of the women are very young (less than 20 years of age) and form $10.39 \%$ of the sample. The biggest group was in the 21-30 years age group (39.62\%) and the next biggest was the $31-40$ years age

${ }^{15}$ Indiagriline.com. group $(22.64 \%)$. These two groups of women form a significant proportion of the larger Indian population and the important functions of child bearing and rearing are performed at these age levels and hence the views of these women on the new communication technology were considered significant.

One of the greatest cultural borders for the female child in India is education. When the allocation of resources is made in the family, a girl child gets less food and health care than her male sibling and this has resulted in a declining female population. (There are only 933 women to 1000 males in the larger Indian population ${ }^{16}$.). Since the objective of development is to improve living conditions for society as a whole, it is logical to expect that this also means an improved status for women. For a long time it was generally assumed that development automatically improved women's status. Yet, starting with the pioneering work of Ester Boserup (1970), research has shown that development can even have a deleterious effect on the status of women.

The 2001 Census data reveals that the literacy rate in India for the total population is $65.38 \%$, in which the literacy rate for men is $75.85 \%$, while female literacy is $54.16 \%$.The 2001 Census has pointed out the heartening feature that the "gap in the male-female literacy rates have come down from $28.84 \%$ in 1991 to $21.70 \%$ in $2001^{17}$.

The sample in the rural villages in Figure 2 reflects this national picture and shows a grim $33.96 \%$ of women being illiterate,

\footnotetext{
16 Manorama Yearbook,2002 p 72-76

17 ibid, on social indicators, p 74
} 
while $42.45 \%$ of the sample have obtained a primary school education. A very few $(15.10 \%)$ lucky girl children have obtained secondary education and the rare few $7.55 \%$ - have made it to college. Only $0.94 \%$ has been able to climb the pinnacle of a post-graduate education.

There are many barriers for children's education in general and that of the girl child in particular. While enrolment in primary education has gone up from $42.6 \%$ (1950-51) to $92.14 \%$ (1998-99), the target of universal education is still a long way off ${ }^{18}$.

18 Manorama Yearbook, 2002 on Education, pp 602-608 
Figure 2: Education Levels of Women

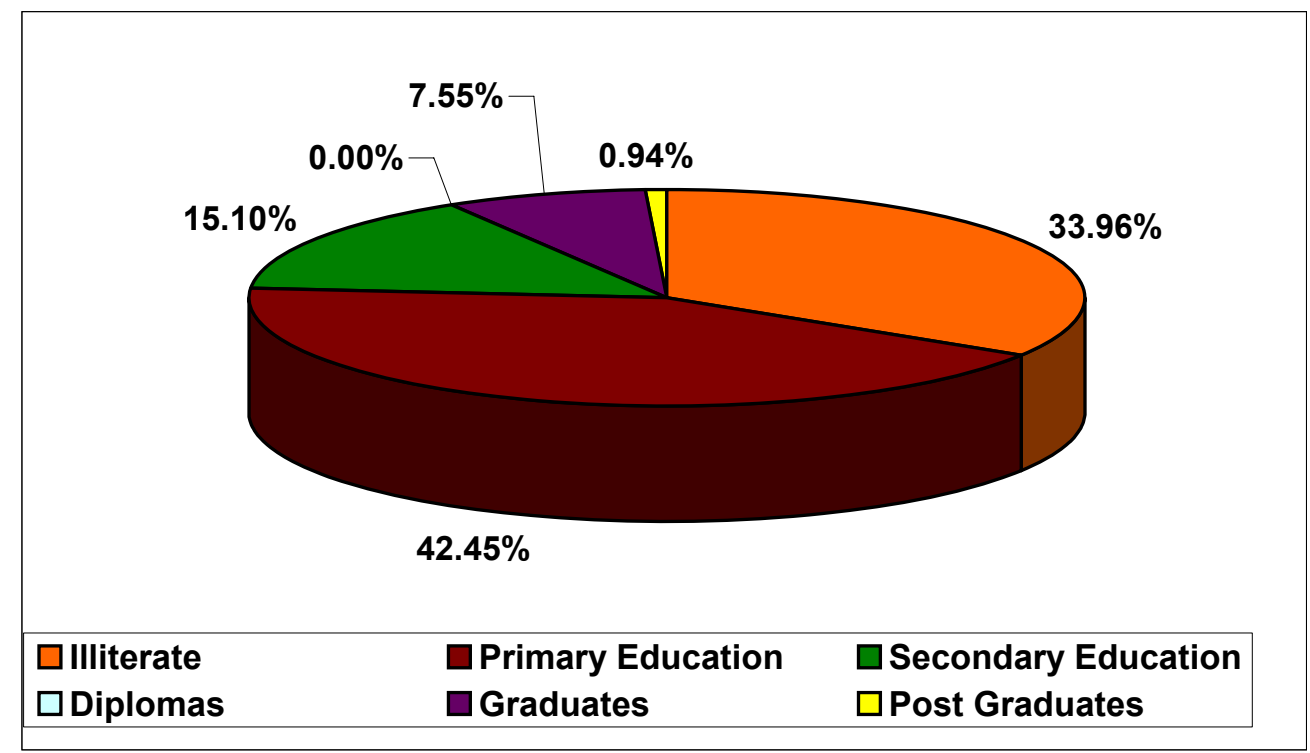

The National Policy on Education (NEP) attempts to provide $94 \%$ of the rural population with a primary school within 1 $\mathrm{km}$ and $84 \%$ with an upper primary school within $3 \mathrm{~km}^{19}$. The presence of a primary school within the village encourages the rural children to enroll, but the presence of often only one teacher for all the subjects taught and constant turnover of teachers often has a negative impact on the quality of education. If there is no school nearby it is enough of a geographic barrier for the girl child to surmount, as education is perceived as being more serious for a male child to make the daily commute. Poor transportation facilities and bad roads are other rural barriers, which are very difficult to cross for a rural child.

The researcher met a very bright young woman running one of the Internet booths in the villages who had dreams of pursuing a medical education, but who stated that she found obtaining even a college education a big barrier which she had to

19 ibid, p. 603 hurdle over. Bus services were available only thrice in a day, at inconvenient times early in the morning, afternoon and late in the evening. At none of these times could she catch a bus to reach a nearby college, which was only a mere $10 \mathrm{kms}$ away. Bad roads made a commute by bicycle or motorcycle a nightmare! So unless the family could design a method of transporting her daily, she had to resign herself to enrolling in a distance education program.

However, the launching of Internet booths in her village opened up new vistas for the transport and traffic of education. She motivated her father, a farmer, to invest in an Internet booth, which she now runs. This young woman said that the Internet was educating her daily and was much more worthwhile than any formal educational system, which anyway was too difficult for her to obtain. This case study illustrates how the new communication technology is empowering women to overcome several barriers! 
Employment is the biggest economic barrier for the rural Indian woman to cross. Being a housewife keeps her occupied from morning till evening, with no monetary compensation for the work done. Most of the women worked as secondary laborers assisting their families, and in this were often not monetarily compensated. This creates not only low self-esteem but generates more poverty as a woman has no capital or other assets through which she can approach banks for loans to start her own businesses or other forms of gainful employment.

Employment is both a possibility and a problem for economic betterment for the rural Indian woman and this is shown in

Figure 3. It was found that $70.75 \%$ of the sample women were housewives. Agriculture is the traditional occupation in the rural areas and only $16.04 \%$ had primary employment in this sector. A very few $(11.32 \%)$ of the women were selfemployed and a very rarly $(1.89 \%)$ held salaried jobs.

\section{Figure 3: Occupation of Women}

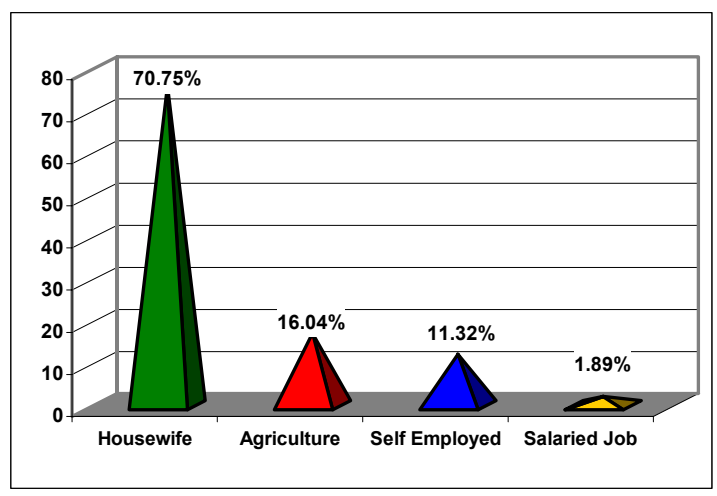

The business house which had started the Internet booths in these rural areas was interested in obtaining information on the educational and training levels of the rural women, along with any hobbies, talents or skills which could be tapped for creating a pool of self-employment economic activities, and asking this researcher to obtain data. When asked open-ended questions on these, the researcher was able to tabulate a wealth of information on the talent and sakthi (energy) available for gainful transformation. Many banks and development agencies are now coming forward to train and fund women in selfhelp groups as micro development is perceived as the new vehicle of development.

Many of the women's families, that is $39.62 \%$, had a monthly income of Rs 1,000 (about US \$ $21-1$ US \$= Rs 47); $43.40 \%$ had an income ranging from Rs 1,0013,000 (about 47- 63.8 US \$); 8.49\% had an income ranging from Rs 3,001- 5,000 (about 63.8 - 106 US \$); $5.66 \%$ had an income ranging from Rs 5,001- 10,000 (about 106-212 US \$) and very few rich families had monthly incomes over Rs 10,001 (above 212 US \$). Figure 4 represents the financial data but is not adequate to represent the depths of rural poverty and rural indebtedness.

Agriculture is the most crucial sector in the Indian economy for it provides food security to the mammoth one billion population, generates employment, helps to alleviate poverty and contributes significantly to the country's exports. From 50 million tons in 1950, food grain production (rice, wheat, coarse grains and pulses) had risen to 208 million tons in 1999-2000, the highest on record ${ }^{20}$.

\footnotetext{
${ }^{20}$ Malayala Manorama 2002 on Agriculture, pp 34-42.
} 


\section{Figure 4: Family Income (in Rupees)}

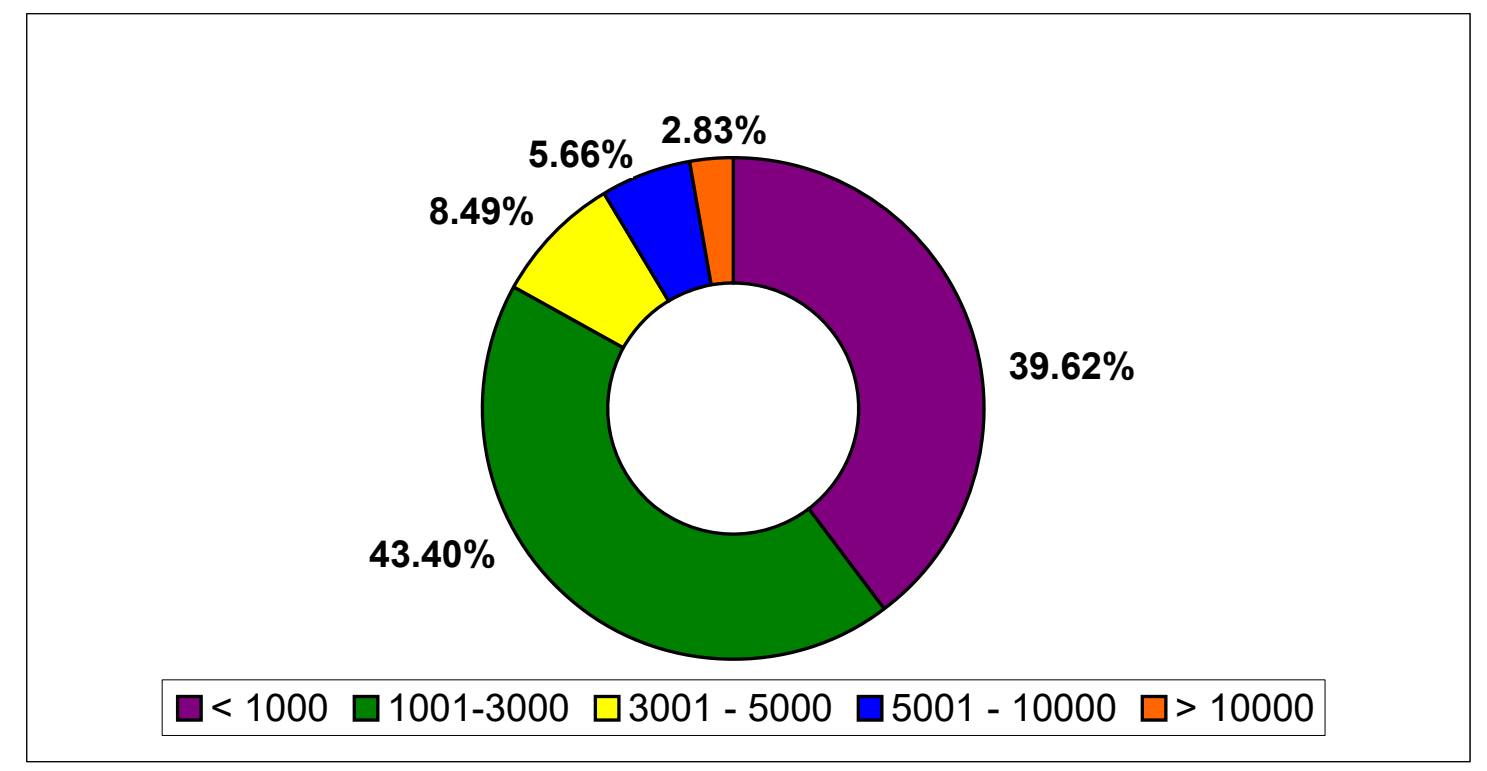

However, the same agriculture is the greatest economic barrier for rural Indian women. Poverty and rural indebtedness are the lot of these families. Incessant hard labor throughout the year do not yield adequate returns as failure of monsoon rains, drought, pile up of food grains in storage, poor procurement prices and the threat of globalization bringing with it imports of food grains from developed countries under the multi-lateral trading system, add to the stockpile of miseries. Rural suicides are very common phenomenon in rural India.

This researcher met a very articulate and informed rural woman, who was the owner of an Internet booth. She narrated that one of her dreams in life was to have a debt-free life. Her father had given her 25 sovereigns (1 sovereign $=8$ grams) of gold as dowry during her wedding and through the years, because of the low returns on agriculture, her husband had constantly pledged her jewelry to the local moneylender. Her joke that "the only quarrel I have with my husband in all these years is about the pledging of my jewelry" revealed the great economic distress of this family.

However, all these factors did not dampen the spirit of this woman for she formed a local Self-Help Group (SHG) in her village. Every week/fortnight when this SHG met, she would compulsorily switch on her computer and open the website of Indiagriline.com as learning the contents of at least one page was the agenda for each single meeting. They would learn about new hybrid seeds, pesticides, fertilizers and best market prices. From being mere secondary workers in their families, empowered by the Internet, they moved to becoming primary agricultural workers. Browsing on the Net, the women of this SHG learnt that their village had been classified as a "town" and so approached the Panchayat (the local government) to approach the Rural Administration wing of 
the Government to redress their local problems. These women, because of the new communication technology, had crossed an important political barrier!

The Committee on the Status of Women in India (CWSI) has been convinced that there is a definite link between the increasing devaluation of women in the economy with the failure of political and legal equalityguaranteed by the Constitution- to transform the status of women in India ${ }^{21}$. This reduction in rural women's economic status is often traced to a patriarchal society, with an emphasis on the traditional values of housework and the elite model of behavior in which a "non-working" status is identified as an indicator of a higher status. This cultural barrier is being overcome with education, mobility and professionalism of the work place. The Internet, by offering information, education and economic opportunities within the private and close confines of a computer, is new window of opportunity for the rural women of India. Structural changes like land reform, like joint registration of land titles of husband and wife, alone can lead to distributive justice and social transformation ${ }^{22}$.

Films, drama and other mass media in the 1950's and 1960's portrayed Indian families in general and rural families in particular as being large extended families following the traditional pattern of a "joint family" in which several generations lived under one roof, cooked food in a common hearth and shared resources and religious festivals together and owned property jointly. This scenario seems to be changing, for in the sample, it is seen that only $23.58 \%$ of families, live in joint families while the predominant group of

\footnotetext{
21 Vina Mazumdar in Rekha Mehra and $\mathrm{K}$. Saradamoni (1983), p 6.

${ }^{22}$ Ibid, "Changing Land Reforms and Women", pp35-146.
}

$76.42 \%$ live in nuclear families. Figure 5 reflects these features of rural families.

\section{Figure 5: Family Type}

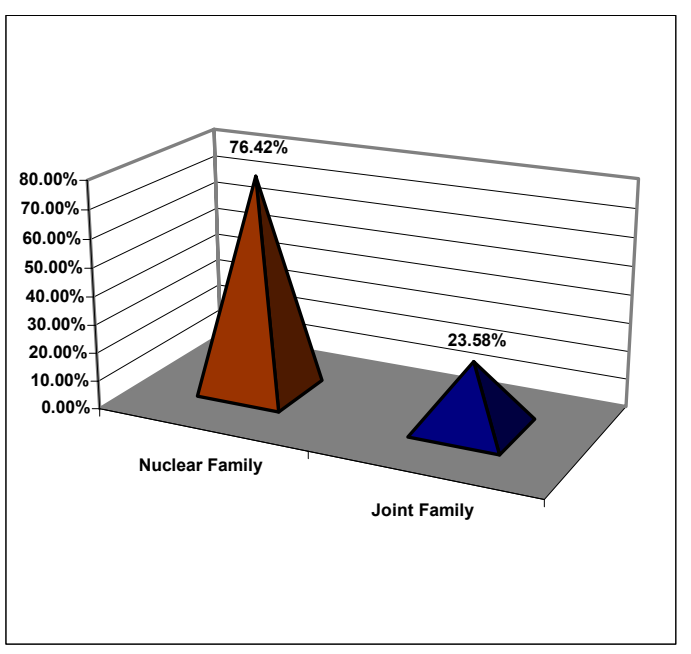

It is very encouraging to note that rural Indian women have been able to cross personal and cultural barrier in even determining the type and size of the family in which they want to dwell in. While living in a nuclear family with spouse and children, working for greater freedom and independence is a mixed blessing in the rural scenario, in which land holdings become fragmented through division within the family.

It was also refreshing to see a young woman with a post-graduate education in computer science, who runs an Internet booth, living in a huge joint family of nineteen members. Her father, though a farmer, runs the village post office and his four brothers with their wives and six children live with them under one roof .Her brother was obtaining a college education through a distance education program, just like she had done earlier, and was helping her run the booth.

This young woman was held as a role model for rural transformation, for though she 
belonged to an affluent family, she ran the Internet Booth very professionally and used it as a tool for individual, family and village development. She developed several marketing strategies for "selling" the Internet to the villagers, designed wedding cards and stationery and sold them to village people, and strongly motivated village children to become computer literate.

How did this young village woman develop so much of savvy? She said it was from the various women in her family with whom she interacted on a daily basis. From her grandmother, the matriarch of the family she learnt community development as this grand old lady had been the head of the Mahila Mandal in her times. From her numerous aunts she was motivated to get an education for most of them had obtained a college degree. From her mother and others she learnt to contribute to the daily family routine of joint production of goods and services.

From the men folk in the family she learnt the value of economic enterprise and so when her father started the Internet booth she took over its economic activities. Hence the joint family has been one of the key factors responsible for the empowerment of this young woman, who is traditional yet modern.

Family size is an important demographic indicator, and it is interesting to note that the family size has also declined in rural India. Families with 2-5 members form $67.93 \%$ of the sample; $24.53 \%$ of the sample are families of 6-8 members. Big families of 9-11 members are only $6.6 \%$, and only $0.94 \%$ of the sample is families with over 15 members. Figure 6 reflects these figures.
Figure 6: Family Size

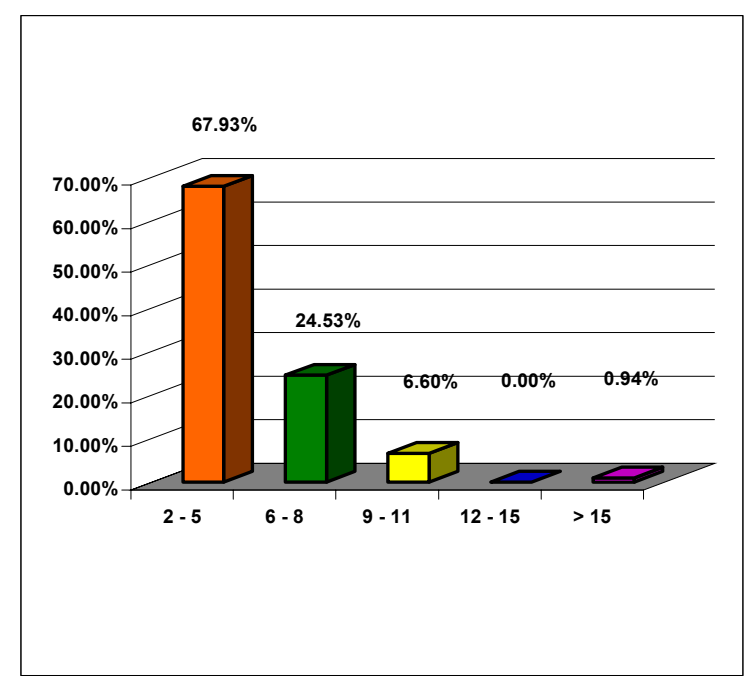

These rural women have determined personal boundaries by choosing the size and type of family, and it shows an important mindset, that these women are ready to take charge of their lives. This is also revealed in the data on the number of children, in each family. While only $2.83 \%$ of the sample had no children, the greater proportion of them, $55.66 \%$ have $1-2$ children and $31.13 \%$ have $3-4$ children. Very few, 7.55\%, have 5-6 children, and only $2.83 \%$ have more than 6 children. All this is portrayed in Figure 7 given below. 
Figure 7: Number of Children

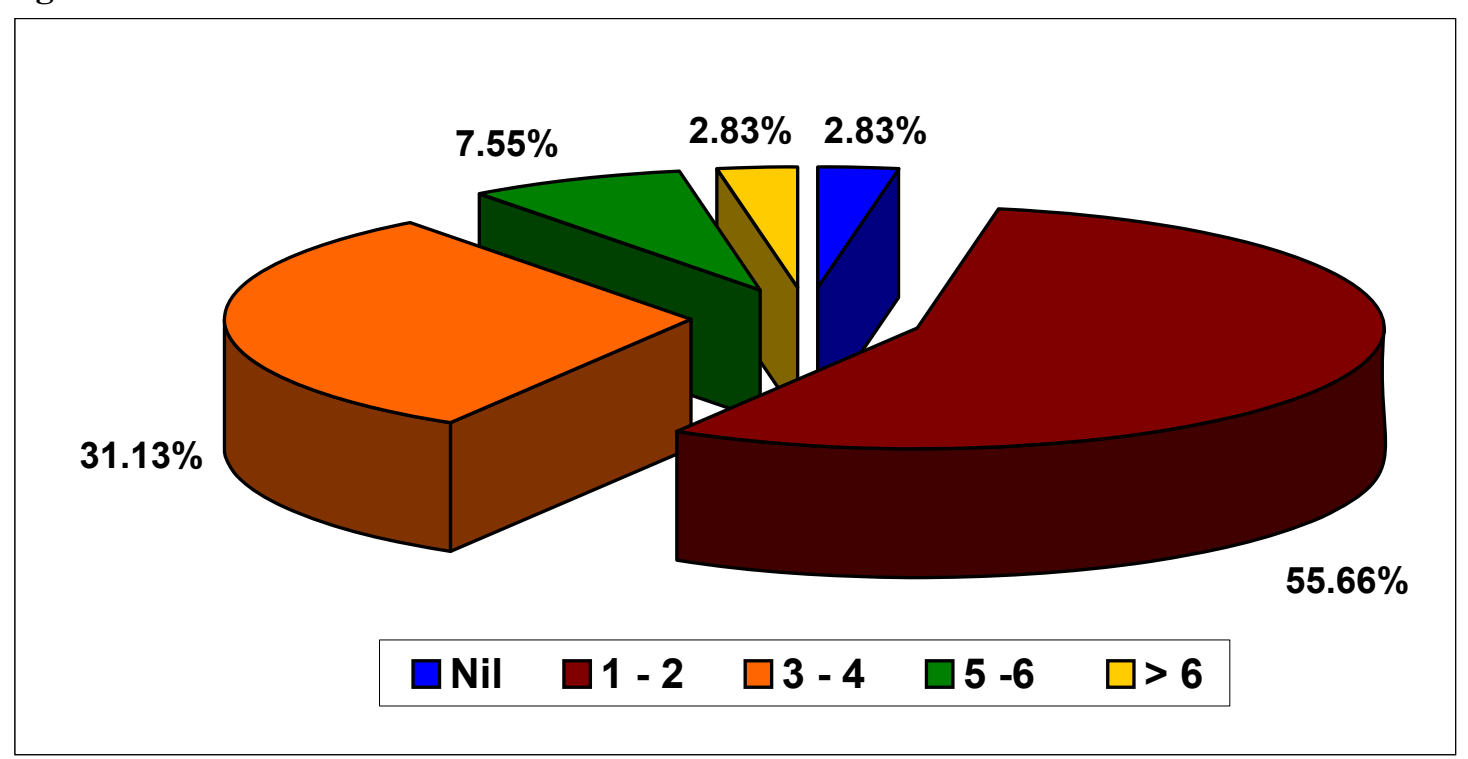

It was heartening to note that there has been a systematic decline in the birthrate and this reflects the national statistics. Though the Decennial Census of 2001 indicates an addition of 181 million people between 19912001 , the rate of growth shows the sharpest decline of $21.34 \%$ since Independence ${ }^{23}$.

There are wide variations between the States in this regard. While Bihar recorded the highest increase of $23.38 \%$, the lowest growth rate was in Kerala - 9.42\%, followed by Tamil Nadu $-11.19 \%$, and by Andhra Pradesh $-13.86 \%{ }^{24}$.

Information and its attendant information media are to the Information Revolution what manual labor was to the Agricultural Revolution and energy was to the Industrial Revolution. Hence, the access to and usage of the Internet is considered an important

23 Manorama Yearbook, on the Indian Population, pp 72-77

${ }^{24}$ ibid, p 74. variable of studying rural and village development in India. The Internet booths are the newest media available in these villages of South India, and with their bright yellow signs they beckon the passerby to visit them.

Of course, India has a long way to go on the road to information development. Though high income countries such as the 23 nations (mainly in Europe and North America) comprising the Organization for Economic Development (OECD) represent $15 \%$ of the world's population they account for $97 \%$ of Internet host computers, $91 \%$ of all Internet users, and $68 \%$ of the world's telephone (Mansell and When,1998). The new telecom policy together with the New Economic Policy in India have thrown open the Internet in India, which is maximizing reach and richness. Mass customization has become a reality in India!

The market research firm Gartner Dataquest has stated in a recent report that India is expected to reach the highest growth rate in the Internet market in the Asia Pacific region 
in the next five years ${ }^{25}$. From 2001-2005, India is expected to enjoy an average Internet subscriber growth of 44 per cent a year. The report continues to state that the Asia Pacific region, led by China and Japan and an emerging market in India will overtake the U.S as the world's largest Internet market within the next three years.

\section{References}

Bahadur, S. 1999. 'DOT (Demystified)'. Information Communication World, special supplement, August, pp11-20.

Balakrishnan, A. 1999. 'India, Still Internet Shy'. Computers Today, 1-15, July 1999.

Bhatt, S. C. 1994. Satellite Invasion of India. New Delhi: Gyan Publishing House.

Boserup, Esther. 1970. Women's Role in Economic Development. London: Allen and Unwin.

Chowdary, T. H. 1998. 'Politics and Economics of Telecom Liberalization in India'. Telecommunication Policy, $22(1)$, pp 9-22.

Contractor, N. S., Singhal, A . \& Rogers, E. M. 1988. 'Meta Theoretical Perspectives on Satellite Television and Development in India'. Journal of Broadcasting and Electronic Media, 32 (2), pp 129-48.

Creedon, Pamela.J. (ed.). 1993. Women in Mass Communication. New Delhi: Sage Publications.
Fernandez, M. 1998. 'Asian Indian Americans in the Bay Area and the Glass Ceiling' in Sociological Perspectives, 41 (1), pp 119-49.

Hornik, R. C. 1998. Development Communication: Information, Agriculture and Nutrition in the Third World. New York: Longmans.

Jhunjhunwalla, A., Ramamurthi, B and Gonsalves, T.A 1998. 'The Role of Technology in Telecom Expansion in India' in I.E.E.E. Communications Magazine. December, 1998.

Johnson, K. 2000. Television and Social Change in Rural India. New Delhi: Sage Publications.

Kumar, K.J.1998. 'History of Television in India: A Political Economy Perspective' in S.R.Melkote, P.Shields, \& B.C.Agrawal (eds), International Satellite Broadcasting in South Asia: Political, Economic and Cultural Implications. pp 19-46. New York: University Press of America.

Malhotra. S. and Rogers, E. M. 2000. Satellitte Television Networks and the New Indian Women. Paper presented to the Western States Communication Association, Sacremento, Feb 2000.

Manorama Yearbook 2002. Kottayam: Manorama Yearbook Press.

Manorama Yearbook 2004. Kottayam: Manorama Yearbook Press.

${ }^{25}$ rediff.com 
Mansell. R and When. U. (eds). 1998. Knowledge Societies: Information Technology for Sustainable Development. New York: Oxford University Press.

McDowell, S. D. 1997. Globalization, Liberalization and Policy Change: A Political Economy of India's Communication Sector. New York: St.Martin's Press.

Mehra, Rekha and Saradamoni, R. 1983. Women and Rural Transformation. New Delhi: ICSSR and Centre for Women's Development Studies.

Melkote. S. R. 1991. Communication for Development in the Third World: Theory and Practice. New Delhi: Sage Publications.

Mody, B. 2000. The Internet in a Majority World. ICA News, March 2000, p 11.

Morgan, Robin. 1984. Sisterhood is Global. New York: Anchor Press.

Nair, K.Sadanandan, and Shirley A. White (eds.). 1993. Perspectives on Development Communication. New Delhi: Sage Publications.

Natarajan, A. 2000. Start-up Fever in India. Siliconindia, Feb 2000, pp 62-66.

Pitroda, S. 1993. 'Development, Democracy and the Village Telephone' in Harvard Business Review. 71(6), pp 66-77.

Pitroda, S. 1998. 'Changing IT Focus: From Industry to People' in Silicon India. Dec 1998.
Riano, Pilar (ed.). 1994. Women in Grassroots Communication: Furthering Social Change. New Delhi: Sage Publications.

Servaes, Jan, Thomas L. Jacobson and Shirley A. White (eds.). 1996. Communication and Human Values: Participatory Communication for Social Change. New Delhi: Sage Publications.

Singhal, A and Rogers, E.M. 2001. India's Information Revolution: From Bullock Carts to Cyber Cafes. New Delhi: Sage Publications.

Sundari. K. 2000. 'Use of Information Technology for Community Development in A Field Study of the Information Booths of MSSRF at Pondicherry, Research report, Stella Maris College ( Autonomous), Chennai.

Sundari. K. 2001. 'Probing Beyond Paradigms Through Case Studies from India-Information Technology for Women'. Paper presented at the $\mathrm{XV}$ Congress of the International Sociological Association at Brisbane, Australia, July 7-13, 2002.

Sundari. K. 2001. 'Communication Across Borders- Experiences of Rural Indian Women in Using Cyber Cafes'. Paper presented at the 53rd annual conference of the International Communication Association at San Diego, California, May 23-27, 2003.

Tehranian, M. 1994. 'Communication and Development' in D. Crowley and D. Mitchell (eds) Communication Theory Today. CA: Stanford University Press, pp 274-306. 
MANUSYA: Journal of Humanities (Special Issue No.8 2004)

Vittal, N. 1999. 'IT Strategy: India's New Lever of Growth' in Computers Today. 1-15, July 1999.

Westerveld. R and Prasad, R. 1994. 'Rural Communications in India Using Fixed Cellular Radio Systems' in I.E.E.E. Communications Magazine, October, pp 70-77.

White, Shirley, Nair, K. S, and Ashcroft, J. (eds). 1994. Communication and Human Values: Participatory Communication: Working for Change and Development. New Delhi: Sage publications. 